\title{
Model osoby vo filozofii J. Locka
}

\author{
Vladimír Manda \\ Univerzita Konštantína Filozofa v Nitre, SK
}

MANDA, V.: Model of Person in J. Locke's Philosophy.
Philosophica Critica, vol. 4, 2018, no. 1, ISSN 1339-8970, pp. 35-42.

John Locke is in philosophy, among other things, the initiator of a new perspective on the problems associated with the understanding of the personality of man. The literature focuses primarily on his theory of person's identity, and less attention is paid to the so-called nonsubstantive ground of a person. Locke, in his views on the person, casts doubt on the traditionally emphasized decisive role of the "spirit" substance for the person. Therefore, if a person is not determined by the spirit, what or who is the main determinant of the human's person? From the superficial reading of Locke, it would seem that the essential foundation of a human being is his memory. It is staying without the attention that behind the memory of the person stands his conscious and voluntary activity, which is reflected in his memory. On this base we could say that Locke is the first philosopher who, though indirectly, said that a person is a product of purposeful human's activity.

Key words: Human Being - Person - Material Substance - Spirit Substance - Consciousness - Memory

Jednou z významných tém filozofie 17. storočia bola aj téma človeka a jeho osoby. Nesporne k významným iniciátorom zásadne nového pohl’adu na človeka patria T. Hobbes, J. Locke a J. J. Rouesseau. Hobbes bol prvým filozofom, ktorý odmietol tradičný aristotelovský model človeka. Človek podla Hobbesa nie je od prírody spoločenskou bytost'ou v tom zmysle, že by vedel žit' v občianskej spoločnosti, kde dominujú nie príbuzenské vzt'ahy, ale vzt'ahy, ktoré si vyžadujú dohody a záruky. Vediet' žit' v rodine a vediet' žit' v občianskej spoločnosti sú dve podstatne odlišné schopnosti. Aby človek mohol žit' v občianskej spoločnosti, k tomu mu nestačí jeho vrodená „spoločenskost'“, tu si musí osvojit' tzv. druhú prirodzenost', alebo schopnost' rešpektovat' zákony občianskej spoločnosti plynúce zo vzájomných dohôd. „Človek je preto uspôsobený žit' v spoločnosti nie na základe prirodzenosti, ale na základe výchovy“ (Hobbes 1988, 134). J. Locke je iniciátorom predovšetkým nového pohl'adu na osobu človeka, ktorá nie je daná duchovnou substanciou ako takou, 
ale skôr teoretickou a praktickou aktivitou človeka. Preto možno v jeho prípade hovorit' o nesubstanciálnom modele osoby človeka. J.-J. Rousseau premenil spoločenskú formu človeka na úpadkovú formu a jeho pôvodnú prirodzenú formu vyzdvihol a premenil na „zlatý“ vek človeka (St’ahel 2015, 106 -113).

Analýze pojmu „osoba“ sa Locke venuje najmä v práci Rozprava o l’udskom rozume (1690), v 27. kapitole druhej knihy, ktorá je všeobecne venovaná problematike identity a rozdielnosti. Už začlenenie problematiky osobnosti do kapitoly o identite a diferenciácii naznačuje, že hlavným zámerom Locka tu nie je komplexná analýza pojmu osoby, ale skúmanie identity osoby. Problém, ktorý pre krest'anov, ale aj pre praktický pozemský život človeka nie je len akademickou otázkou v prípade, že sa posudzuje zodpovednost' človeka za jeho činy. Ved' identita osoby je spätá s jej zodpovednost'ou za vlastné skutky a $\mathrm{v}$ určitom zmysle predstavuje morálny rozmer človeka. Preto Locke v záverečnej časti venovanej osobe upozorňuje na to, že výraz osoba je právnický výraz pre človeka. „Je to právnický výraz, ktorý sa vzt'ahuje na skutky a ich odmenu a používa sa len vo vzt'ahu k rozumom obdareným a konajúcim bytostiam, pre ktoré jestvujú zákony a ktoré môžu byt' št’astné a nešt’astné" (Locke 1983, 293).

$\mathrm{Z}$ vecného hl'adiska vymedzuje Locke osobu „ako mysliace inteligentné bytie, ktoré má rozum, schopnost' uvažovat' a seba môže vnímat’ ako seba, t. j. ako tú istú vec, mysliacu bytost' v rozličnom čase a na rozličnom mieste. Robí to iba prostredníctvom vedomia, ktoré je od myslenia neoddelitel'né a podl'a mňa patrí k jeho podstate" (Locke 1983, 279). Všeobecné vymedzenie osoby d'alej konkretizuje nasledujúcim spôsobom: „Ved' nie je možné, aby niekto vnímal bez toho, aby vnímal, že tak robí. Ked' niečo vidíme, počujeme, voniame, chutnáme, pocitujeme, zvažujeme alebo chceme, vieme že tak robíme. To platí vždy, ked' ide o prítomné pocity a vnemy. Preto je každý pre seba tým, čo nazývame vlastným Ja“ (Locke 1983, 279).

Aby sme lepšie porozumeli Lockovmu vymedzeniu osoby, je potrebné si pripomenút' predovšetkým Lockove epistemologické východisko, ktoré sa výrazným spôsobom prejavuje aj v jeho chápaní osoby. Locke pri analýze l'udského poznania vychádza z existencie mysle, ktorá je duchovnou, t. j. nemateriálnou substanciou a na počiatku je akoby nepopísaným čistým papierom. To znamená, že vo svojom obsahu nedisponuje žiadnymi vrodenými ideami (Locke 1983, kap. 1). Tieto sa do mysle dostávajú postupne na základe skúsenosti, či už zmyslovej, vonkajšej alebo vnútornej skúsenosti, t. j. reflexie. Idey, ktoré vstupujú do obsahu mysle sa stávajú predmetom uvedomovania, stávajú sa vedomými ideami a prostredníctvom ich uvedomovania sa postupne formuje identita osoby, t. j. Ja.

Vd'aka skutočnosti, že máme aj pamät' dochádza k tomu, že či už teoretické alebo praktické činy človeka sa v podobe reflektovaných ideí „akumulujú“ vo vedomí člo- 
veka a postupne začínajú dávat’ človeku špecifický a jedinečný charakter, plynúci z jeho vlastných jedinečných aktivít. Človek sa prostredníctvom svojich vedomých aktivít, zameraných predovšetkým na realizáciu jeho základných potrieb stáva tým, čomu sa hovorí osoba človeka. Prostredníctvom ideí v pamäti sa osoba vzt'ahuje nielen na aktuálne činy, ale z hl'adiska časového sa osoba, obrazne povedané „rozprestiera“ aj na minulé stavy a činy. Ide samozrejme o tie stavy a činy, ktorých idey sme si schopní prostredníctvom pamäti tak povediac sprítomnit’ v súčasnom vedomí a uvedomit' si ich ako idey prináležiace nášmu Ja. Preto Locke konštatuje, že : „Pokial' sa dá toto vedomie rozšírit’ smerom dozadu na nejakú minulú činnost' alebo myšlienku, potial' siaha identita tejto osoby. Teraz je tým istým Ja, akým bolo vtedy a tú činnost' vykonalo to isté Ja, ktoré teraz o tom premýšl’a“ (Locke 1983, 279).

V súvislosti s osobou človeka sa Locke hned' na počiatku odkláňa od scholastickej tradície a podstatne iným spôsobom vymedzuje vzt'ah medzi človekom a osobou. Podl'a scholastickej tradície platí, že každý človek v dôsledku toho, že je stvorený $s$ jedinečnou dušou, je aj jedinečnou osobou. Nemôže existovat' človek a nebyt' pritom osobou (Moreland - Wallace 1995, 322). Opačne to však neplatí. Nie každá osoba je človekom. Pojem osoby je logicky nadradený pojmu človeka, t. j. je širší ako pojem človeka. Je to dôsledok toho, že napríklad aj Boh je osobou, ale nie je človekom. Teda pojem osoby je širší ako pojem človeka. Locke uvedený vzt'ah obracia a tvrdí, že všeobecnejším pojmom je pojem človeka a osoba je len určitou podobou človeka. Uvedený obrat má v sebe skrytý silný protináboženský pohl'ad na človeka. Zo scholastického pohl'adu Boh tvorí osobu človeka na svoj obraz. V Lockovom podaní Boh tvorí človeka, ale nie súčasne ako osobu, teda ako bytost', ktorá by bola schopná konat' rozumne a ciel'avedome od počiatku, pretože človek sa rodí na svet nahý nie len vo fyzickom, ale aj v duchovnom zmysle. Svoju osobu, teda bytost', ktorá je schopná konat' rozumne, ciel'avedome a tým aj morálne, si prirodzený človek musí osvojit' tým, že si osvojí rozum a schopnost' ciel'avedomého konania. Podoba osoby človeka a osoby Boha je teda v prípade Locka dôsledkom vlastnej aktivity samotné-ho človeka a nie Boha.

Jednou z príčin Lockovho obratu v danej veci je jeho epistemologické stanovisko, na základe ktorého sa človek nerodí so žiadnou vrodenou ideou a teda ani nemôže byt' osobou, pretože podstatným znakom osoby je myslenie, odlišovanie dobra od zla, čo bez rozvinutého poznania nie je možné. Preto napríklad malé deti nie sú osobami, človek s poškodeným mozgom by sa osobou stat' nemohol a pod. Teda pre Locka platí, že nie každý človek je osobou, človek sa osobou stáva v tej miere, v akej si osvojuje schopnosti osoby.

Na uvedenom základe sa potom odlišuje identita osoby od identity človeka. Ak uvažujeme, čo je v človeku počas jeho života identické, tak prichádzame k záveru, že človek je vo svojej podstate biologická bytost' a to, čo je pre ňu identické, teda to isté od narodenia až po smrt', je jej individuálny život. Individuálny život započatý 
narodením a skončený smrt'ou je to, čím sa jeden človek odlišuje od druhého a život je tým prvkom, ktorý zjednocuje rozmanité zmeny či už v tele alebo v psychike človeka do identity daného človeka (Locke 1983, 285 - 286). V tej miere, v akej sa mysel' človeka začína napíňat' ideami, ktoré si uvedomuje ako svoje idey, v tej miere, v akej človek začína mysliet' a rozhodovat' sa pre svoje činy, v tej miere sa človek stáva osobou. Identita osoby sa od identity človeka odlišuje v tom, že Ja, ktoré je všeobecným výrazom identity osoby si „privlastňuje“ len idey tých činov a tie názory, ktoré reflektuje ako svoje vlastné, t. j. sú dôsledkom činov vedených jej vlastnou vôl'ou, jej vlastným rozhodovaním. To, čo zjednocuje činy osoby, či už praktické alebo teoretické, do jej všeobecného identického Ja, je tá istá vôl'a osoby, ktorou sú uvedené činy „presiaknuté“. Na rozdiel od identity osoby, identita človeka nie je daná jeho vlastnou ciel'avedomou aktivitou, ale časom a miestom jeho narodenia, zrodom individuálneho života, ktorý však nie je výsledkom jeho vlastnej aktivity a teda nemôže niest' za zrod svojho individuálneho života zodpovednost'.

Ak budeme na osobu nahliadat' $\mathrm{z}$ hl'adiska jej vecného obsahu a nie $\mathrm{z}$ hl'adiska jej identity alebo totožnosti, potom sa obsah osoby začne diferencovat' na rozmanité idey, ktorých rozmanitost' je podmienená rôznost'ou času, miesta, situácií, do ktorých sa osoba vo svojej aktivite dostáva, a v ktorých reflektuje samu seba, svoju vôl'u. Práve z hl'adiska obsahu osoby možno hovorit' o jej zmene alebo dokonca o určitom vývoji osoby, ktorý začína prvou uvedomenou ideou a postupne sa obohacuje o nové idey. Tak, ako sa na jednej strane obsahom osoby stávajú nové a nové idey reflektujúce jej vedomú a dobrovol'nú aktivitu, tak sa na strane druhej vedomie týchto ideí stáva stále všeobecnejším.

Iným významným aspektom Lockovho chápania osoby je jeho interpretácia vzt'ahu osoby a materiálneho tela alebo substancie, ako aj vzt'ahu osoby a duše alebo mysliacej substancie. Locke v rozpore so stredovekou, ale aj karteziánskou tradíciou trvá jednoznačne na diferenciácii osoby a mysliacej duše a súčasne zdôrazňuje, že osoba nie je nutne spätá s jednou mysliacou substanciou. Locke v tomto smere hovorí: „Lebo identita osoby spočíva iba v tom, že je to isté vedomie, ktoré spôsobuje, že človek je pre seba ten istý, pričom nezáleží, či je to vedomie spojené s jednou substanciou alebo pretrváva v rozličných po sebe nasledujúcich substanciách. Pokial' môže nejaká rozumná bytost'o opakovat' ideu nejakej minulej činnosti s tým istým vedomím, aké malo o nej prvý raz a s tým istým vedomím, ktoré má o nejakej terajšej činnosti, potial' je to isté osobné Ja“ (Locke 1983, 280 - 281). Lockov dôraz, s akým sa snaží oddelit' všeobecné vedomie, t. j. osobu od jej základu, mysliacej substancie alebo duše, neznamená absolútnu oddelenost' osoby od mysliacej substancie. Locke v súlade s tradíciou nepochybuje o tom, že osoba človeka je okrem iného aj prejavom mysliacej substancie a bez nej by žiadnej osoby nebolo. To čo odmieta uznat', spočíva v tom, že identita osoby je podmienená numericky tou istou mysliacou substanciou. A odmieta to uznat' najmä preto, že o mysliacej substancii, o jej 
povahe, toho vel'a nevieme, takže nemáme jasné dôkazy o tom, že osoba človeka sa opiera o identickú mysliacu substanciu.

Je zrejmé, že uvedené stanovisko je okrem iného dôsledkom Lockovej empirickej metodológie, na báze ktorej nám nielen mysliaca, ale aj nemysliaca substancia nie je daná zmyslovo. To čo je nám zmyslovo dané sú len rozmanité idey. Na základe pocit'ovania, vnímania a myslenia usudzujeme, že základom týchto našich schopností je nejaká mysliaca substancia alebo duša obsiahnutá v našom tele, ale jej bezprostredné zmyslové vnímanie nám nie je prístupné. Nemôžeme si ju zmyslovo obzriet' tak, ako si môžeme obzriet' napríklad strom, ktorý vnímame.

Špecifickým argumentom spochybňujúcim istotu o existencii identickej mysliacej substancie je názor o tom, že mysliaca substancia nie je neustále činná. Napríklad počas spánku. Ak by naša mysliaca duša bola aktívna aj počas spánku, tak by sme museli mysliet', aj ked' spíme. Skúsenost' nám ukazuje, že ked' spíme, tak nepremýšl'ame, t. j. duša nie je činná. Ak sa ráno zobudíme to, čo obnovuje našu osobu je, naše vedomie o súčasných a minulých stavoch. Uvedomujeme si súčasný stav a ten spájame s uvedomovaním si včerajších a iných minulých ideí. A to všetko zjednocujeme stále do toho istého vedomia, do Ja. V rámci daného procesu podla Locka však nemáme možnost' zist'ovat', či duša alebo mysliaca substancia, prostredníctvom ktorej si ráno uvedomujeme svoju osobu, je tá istá, prostredníctvom ktorej sme si uvedomovali svoju osobu včera. Ved' aj naše telo, ktoré je akoby vonkajšou formou osoby, sa zo dňa na deň postupne mení, t. j. numericky to nie je jedno a to isté telo. Prečo by potom duša mala byt' stále tou istou dušou? Podl'a Locka by sme mohli prijat' predpoklad identickej mysliacej substancie spojenej s jednou osobou za podmienky, že by osoba bola kontinuálnym, neprerušovaným vedomím samej seba. Vo svojom vedomí by permanentne udržiavala idey späté s jej súčasným a celým minulým stavom. V tomto zmysle hovorí: „Ďalej sa spytujeme, či toto Ja je tou istou identickou substanciou. Iba máloktorí by o tom odôvodnene pochybovali, keby tieto vnemy a vedomie o nich boli ustavične prítomné v mysli, čím by tá istá mysliaca bytost' bola vždy vedome prítomná - a ako by sa dalo predpokladat' - očividne totožná sama so sebou“ (Locke 1983, 280 - 281). Ale táto podmienka nepretržitého vedomia na základe našich skúseností nie je splnená. Naše vedomie samých seba sa prerušuje nielen počas spánku, ale aj v dôsledku iných okolností, napríklad stavom opitosti. Preto sa aj otázka identity mysliacej substancie komplikuje.

Lockov útok proti tradičnému scholastickému substančnému modelu osoby, ktorý sa opieral o identitu mysliacej substancie, a ktorý bol iným spôsobom reprodukovaný vo filozofii R. Descarta, zapadá do celkovej empirickej orientácie Lockovej filozofie. Locke totižto nespochybňoval len l'udskú schopnost' poznania duchovnej substancie, ale rovnako spochybňoval aj našu možnost' poznania materiálnej substancie. Substancia je len človekom predpokladaný nositel' rozmanitých vlastností. Locke v tomto zmysle konštatuje: „Pritom je zjavné a pri skúmaní svojich myšlienok to každý zistí, že pri nejakej substancii, či už je to povedzme zlato, kôň, železo, 
človek... nemá nijakú inú ideu okrem ideí zmyslových kvalít, ktoré podl’a neho v nej sídlia. Predpokladá teda akési substratum, nositel'a kvalít alebo jednoduchých ideí, ktoré vnímal ako dovedna spojené. Čo iné je povedzme idea Slnka než zhluk takýchto rozličných jednoduchých ideí: jasné, horúce, zaokrúhlené, majúce trvalý pravidelný pohyb“ (Locke 1983, 277 - 278). Obdobne v súvislosti s duchovnou substanciou Locke konštatuje: „Tým, že dáme dohromady idey myslenia, vnímania, slobody a sily pohybovat' sebou a inými vecami, získame práve taký jasný vnem a pojem nehmotných substancií, aký máme pri hmotných substanciách. Lebo ked' zložíme dohromady idey myslenia a chcenia alebo silu pohybovat' či zastavovat' pohyb telies a pripojíme k ním substanciu, o ktorej samozrejme nemáme zretel'nú ideu, dostaneme ideu nehmotného ducha" (Locke 1983, 285 - 286).

Lockove odmietnutie zakotvit' sebavedomé Ja, osobu v identickej duchovnej substancii, viedlo k nesubstančnému modelu osoby, ktorej identitu mala zabezpečit' pamät človeka. Ak pamät' osoby nie je schopná danej osobe predviest' ideu minulej činnosti ako jej vlastnú činnost', potial' daná idea činnosti spolu s činnost'ou nie sú súčast'ou osoby. Jednoducho povedané, k osobe človeka na základe uvedeného kritéria pamäti prináleží len to, na čo si osoba spomenie. To, na čo si osoba nespomenie, nie je súčast'ou jej osoby.

Uvedený aspekt Lockovej koncepcie osoby sa stal predmetom kritiky ešte počas jeho života. Zdá sa, že jedným z prvých bol John Sergeant (1622 - 1707), anglický katolícky kňaz a jeden z prvých kritikov Lockovho konceptu osoby opierajúcej sa o pamät'. Jedným z najvýznamnejších kritikov sa stal Thomas Reid (1710 - 1796), škótsky filozof a súčasník D. Huma. Jeho kritika Lockovej osoby opierajúcej sa len o pamät' poukazovala predovšetkým na možnost', že ten istý človek sa môže stat' počas života nositel'om viacerých osôb. Reid hovorí: „Locke vážne tvrdí, že identita osoby spočíva vo vedomí; ak ste si vedomí toho, že ste danú vec vykonali pred dvanástimi mesiacmi, potom toto vedomie $\mathrm{z}$ vás robí skutočne tú osobu, ktorá tú vec urobila. Preto vedomie minulých udalostí nemôže znamenat' nič iné než spomienku na to, čo človek vykonal. Takto sa Lockovým princípom identity stáva pamät' a v dôsledku toho je strata pamäti spojená aj so stratou osobnej identity“ (Reid 2000,17).

Locke si bol naznačených dôsledkov svojho konceptu osoby čiastočne vedomý. Poukazuje na to aj jeho vlastný rozbor osoby človeka, ktorý v stave opitosti vykoná niečo, čo si v triezvom stave nepamätá. V uvedenej súvislosti hovorí: „Nie je však opitý a triezvy človek tou istou osobou? Prečo by ho inak trestali za to, čo spáchal, ked’ bol opitý, hoci si toho neskôr nebol vedomý?“ (Locke 1983, 290). Locke sa snaží nájst' riešenie pre dané prípady v dvoch smeroch. $V$ jednom smere konštatuje, že pri poslednom súde, „ked' sa otvoria tajomstvá všetkých sídc dokorán, možno sa oprávnene nazdávat', že sa nikto nebude zodpovedat' za to, o čom nič nevie, lež prijme svoj rozsudok podl'a toho, ako ho usvedčuje alebo ospravedlňuje jeho svedomie“ (Locke 1983, 290). V pozemskom svete, ktorý sa riadi l'udskými zákonmi, 
sa trest síce vzt'ahuje na osobu, ale vzhl'adom na to, že osoba je obsiahnutá v l'udskom indivíduu, človeku, predpokladáme, že ten istý človek je aj tou istou osobou. Podl'a Locka: „V týchto prípadoch nemôžeme s istotou rozoznat', čo je skutočné a čo predstierané, preto sa nevedomost' v stave opilstva alebo v spánku neuznáva ako ospravedlnenie. Hoci sa trest spája s osobnost'ou a osobnost's vedomím a opilec si azda ani neuvedomuje čo vykonal, predsa ho l'udský súd spravodlivo trestá, lebo sa mu zat’ažujúci čin dá dokázat', ale neprítomnost' vedomia, ktorá by ho ospravedlňovala sa nedá dokázat'“ (Locke 1983, 290).

Na základe vyššie uvedeného je zrejmé, že napriek Lockovým tvrdeniam o tom, že zodpovednost' za činy a následne aj tresty a odmeny sa vzt'ahujú na osoby a nie na substancie, o ktoré sa osoba opiera, v pozemskom živote trestáme skôr človeka ako jednotu materiálnej a duchovnej substancie a nie osobu. Vzt’ah medzi činom a človekom sa dá dokázat', ale vzt'ah medzi činom a osobou sa nedá l'ahko dokázat', pretože si to vyžaduje nájst' jasnú súvislost' medzi zámerom osoby a činom. Najjednoduchším prípadom je, ak sa osoba sama k činu prizná.

Lockova analýza trestu opilca jasne ukázala na nové problémy, ako aj slabost' jeho teórie identity osoby, ktorá sa opiera výlučne o pamät' človeka. Scholastický koncept osoby by s prípadom opilca nemal problém. Človek je tu už od počiatku pod vládou duše, a teda osoby a ak sa človek napríklad opil, tak to bolo preto, že jeho osoba nedokázala odolat’ alkoholu, a preto bola zodpovedná aj za následné „alkoholické" konanie človeka. Lockov koncept osoby, zdôrazňujúci predovšetkým jej zodpovednost' za to, čo si pamätá ako svoje činy, vedie v prípade opilca k tomu, že konanie opitého človeka nie je konaním osoby, ktorej je opitý človek nositel'om, a tak vzniká problém so zodpovednost'ou a trestom. Ako sme videli, Locke uvedený problém jednoducho obišiel, ale nevyriešil. Ak tvrdí, že súd opilca odsúdil spravodlivo za jeho činy, „pretože sa mu dajú dokázat“", tak odporuje svojej teórii osoby, lebo súd, v prípade absencie pamäti osoby o „jej“ činoch v opitosti nemá ako dokázat', že uvedené činy konala daná osoba. Súd môže na základe svedectva iných dokázat', že to konal ten a ten človek, ale nie aj osoba „sídliaca“ v danom človeku. Osoba nie je zodpovedná za konanie opitého človeka, ktorý je jej nositel'om, lebo si nepamätá činy opilca ako svoje vlastné činy. Lockom zdôrazňovaná spravodlivost' posledného súdu problém zodpovednosti osoby v podstate tiež nerieši, pretože, aj ked' Boh urobí osobu zodpovednú za činy, ktorých sa dopustila v opitosti, tak sama osoba sa bude cítit’ nespravodlivo odsúdená, pretože ona sama si na dané činy nepamätá, ergo, to nie sú jej vlastné činy.

Na záver by sme chceli zdôraznit', že Lockov koncept osoby, napriek jeho slabým miestam, prichádza oproti tradičným predstavám vo viacerých smeroch s novými pohl'admi na osobu človeka. Tradičné predstavy chápali osobu človeka bud' ako 
čistú duchovnú substanciu, ako novoplatonici, alebo vo forme scholastického konceptu jednoty tela a duše, pričom osobu konštituuje duša človeka (Moreland - Wallace 1995, 4). Locke najmä v dôsledku svojej empirickej metódy prichádza nielen s predstavou osoby, ktorá nie je zakotvená v numericky tej istej substancii, ale navyše sa v jeho koncepte dostáva do popredia otázka postupného formovania osoby a jej závislost' na jej vlastných činoch.

\section{Literatúra}

HOBBES, T. (1988): Výbor z díla. Praha: Svoboda.

LOCKE, J. (1983): Rozprava o l'udskom rozume. Bratislava: Pravda.

MORELAND, J. P. - WALLACE, S. (1995): Aquinas versus Locke and Descartes on the Human Person and End-of-Life Ethics. In: International Philosophical

Quarterly Vol. XXXV, No. 3 Issue No. 139 Sep. 1995, 319-330.

REID, T. (2000): An Inqiury into the Human Mind on the Principles of Common Sense. Edinburgh: Edinburgh University Press Ltd.

SŤAHEL, R. (2015): Človek, jeho sloboda a vlastníctvo v myslení Jeana-Jacquesa

Rousseaua. In: Manda, V. - St'ahel, R. - Pružinec, T.: Človek sloboda

a vlastníctvo vo filozofii raného novoveku. Bratislava: IRIS, 105 - 167.

Text vznikol v rámci projektu: VEGA - 1/0124/16 - „Ruská a slovenská filozofia osoby v lingvistických a filozofických súvislostiach.“”

doc. PhDr. Vladimír Manda, CSc.

Univerzita Konštantína Filozofa v Nitre

Filozofická fakulta

Katedra filozofie

Hodžova 1

94974 Nitra

Slovenská republika

vmanda@ukf.sk 